\title{
CYTOGENETIC STUDY OF F 1 INTERSPECIFIC HYBRIDS OF THE SECTION Helianthus
}

\author{
Dolgova, T.A. ${ }^{1}$, Yushkina, L.L. ${ }^{2}$ and Popov, V.N. ${ }^{3 *}$ \\ ${ }^{1}$ National Pharmaceutical University, Melnikova, 12, Kharkiv 61002, Ukraine \\ ${ }^{2}$ Yurjev Plant Production Institute, Moskovskiy prospekt, 142, \\ Kharkiv 61060, Ukraine \\ ${ }^{3}$ Kharkiv National Agrarian University, Department of Agronomy, Chair of \\ Genetics and Breeding, Kharkiv Region, p/o "Komunist-1", 62483, Ukraine
}

Received: June 20, 2006 Accepted: September 15, 2007

SUMMARY

Cytogenetic peculiarities during the passing of meiosis were studied in anthers of 7 interspecific $\mathrm{F}_{1}$ hybrids obtained by crossing annual wild species (Helianthus annuus, H. praecox, H. argophyllus) with the cultivated sunflower. The hybrids derived from $H$. annuus and $H$. argophyllus were characterized by a low frequency of aberrations $(6.5-8.6 \%)$, which gives evidence of a good balance of the chromosome complex of these hybrids. The hybrids derived from the crosses between $H$. praecox and the cultivated sunflower were considerably less stable because of a high frequency of aberrations in meiosis (29.6-50.0\%).

Key words: Helianthus, interspecific hybrids, microsporogenesis, aberrations

\section{INTRODUCTION}

The main disadvantage of interspecific plant hybrids is low seed yield which does not allow the hybrids to be widely introduced in selection and genetic research. This problem is present in the genus Helianthus which has 49 wild species differing in type of development (annual, perennial species) and ploidy level (diploid, tetraploid, hexaploid species) (Georgieva-Todorova, 1990). The group of annual wild species is of specific interest since its members can be easily crossed with the cultivated sunflower (Popov et al., 2005; Gavrilova et al., 2003), allows the genes for valuable selection traits, such as abiotic and biotic resistance (Cerboncini et al., 2002; Besard et al., 1997), new cms systems (Jan, 2000) etc., to be introduced from wild species. For a wider use of interspecific hybrids in sunflower breeding, their detailed study is needed including cytological investigations.

\footnotetext{
* Corresponding author: e-mail: vnpop@mail.ru
} 
From practical point of view it is of interest to study the meiosis in interspesific sunflower hybrids resulting from crosses between wild and the cultivated species in so far as it allows to select stable genotypes that can be used in breeding programs for creating heterotic hybrids. Thus the cytogenetic study of interspesific hybrids permits to exchange genes between chromosomes of the crossed species.

The aim of the examination was to study cytological peculiarities of the interspesific hybrids obtained by crossing several annual wild species with the cultivated sunflower.

\section{MATERIALS AND METHODS}

In this study we used the wild annual diploid species of the genus Helianthus ( $\mathrm{n}=17$ ): $H$. annuus L. H-151, H. annuus L. ANN-1064, H. annuus L. ANN-1366, H. praecox Engelm. \& Gray, H. argophyllus Torrey \& Gray (female parent) which were crossed with cultivated sunflower lines X908-B, X1006-B and X1012-B (male parent) to produce interspecific $F_{1}$ hybrids. The cultivated inbred lines used for hybridization were selected at the Yurjev Plant Production Institute. These lines are sterility maintainers. Cytoplasmic male-sterile lines of these maintainer lines have been used at the Institute for the development many commercial sunflower hybrids.

Flower buds of interspecific hybrids were collected at the ontogenetic stage R2 (Schneiter et al., 1981) in morning hours (7-10 a.m.) and fixed in a mixture of acetic acid and alcohol (1:3) for 12 hours. The samples were then washed three times with ethanol and stored in $70 \%$ ethanol at the temperature of $+4^{\circ} \mathrm{C}$. Cell staining was carried out according to Shiaf after hot hydrolysis by Feulgen (Pausheva, 1988). Meiosis was studied on temporary squash preparations in $2 \%$ acetocarmine drop.

On average 3-4.5 thousand cells were analyzed in 3-5 plants of each hybrid combinations. The pairwise comparison of data was performed using the statistical tests of t-Student and ø-Fisher (Lakin, 1980).

\section{RESULTS AND DISCUSSION}

A significant criterion describing the progression of meiosis in interspecific diploid sunflower hybrids is the occurrence of 17 bivalents at diakinesis of pollen meiocytes. In the interspecific hybrids studied, this criterion ranged from 76.2 to 99.0\% (Table 1). High frequency of bivalent chromosome pairing in the crosses between the wild forms and the cultivated sunflower was indicated by the occurrence of close bivalents (4.99-6.59), especially in the hybrids derived from $H$. praecox which had this index at the levels of 2.88 and 2.67. The hybrids with $H$. annuus indicated a high level of the synapsis, which differed in the number of chiasmata per bivalent (1.29-1.40) and meiocytes (21.92-23.80) and which significantly exceeded these criteria in comparison with the hybrids involving $H$. praecox $(1.16$ and $1.17 ; 19.72$ and 19.94 , respectively). 


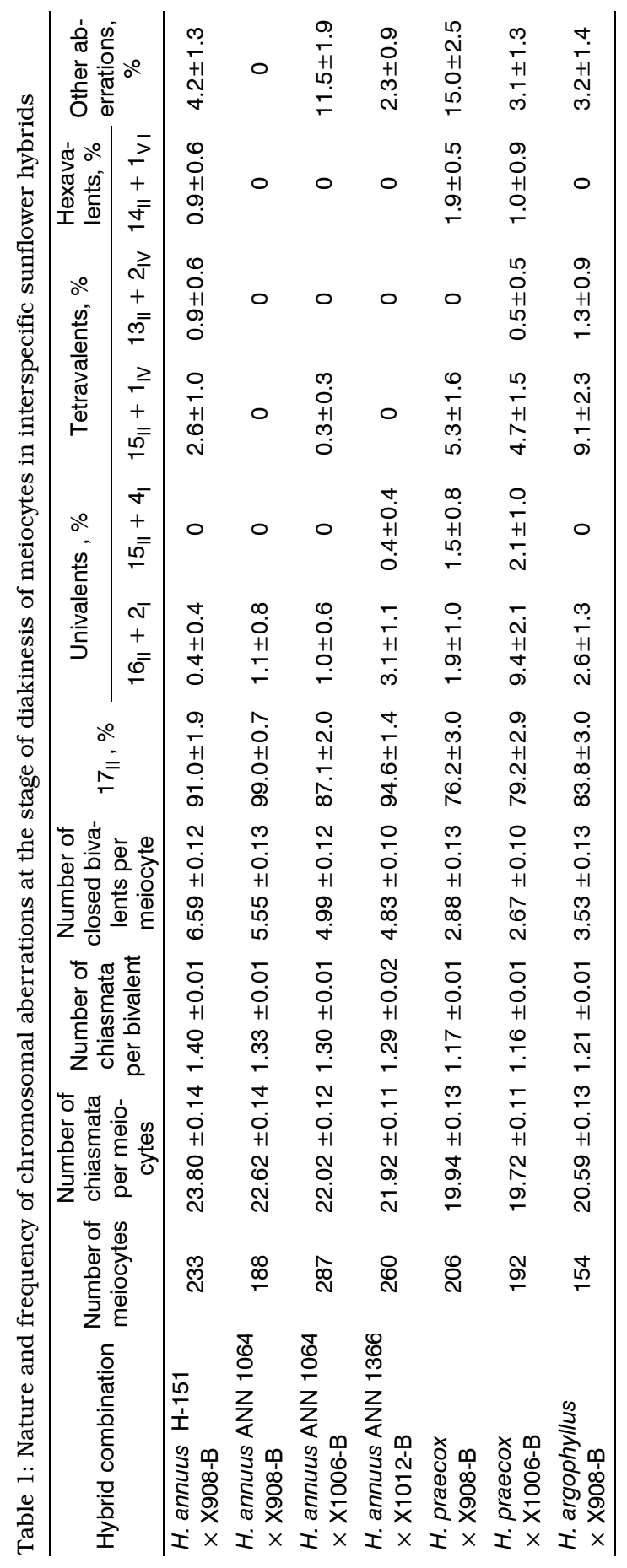


The analysis of chromosome pairing in the interspecific hybrids showed univalents (maximum of their number occurred in $H$. praecox $\times \mathrm{X} 1006-\mathrm{B}: 16_{\mathrm{II}}+2_{\mathrm{I}}$ $9.4 \pm 2.1 \%$ and $15_{\mathrm{II}}+4_{\mathrm{I}}-2.1 \pm 1.0 \%$ ), tetravalents (they predominated in $\mathrm{H}$. argophyllus $\times$ X908-B: $15_{\mathrm{II}}+1_{\mathrm{IV}}-9.1 \pm 2.3$ and $13_{\mathrm{II}}+2_{\mathrm{IV}}-1.3 \pm 0.9 \%$ ), hexavalents (their maximum number occurred in $H$. praecox $\times$ X908-B: $14_{\mathrm{II}}+1_{\mathrm{VI}}-1.9 \pm 0.5 \%$ ) as well as other anomalies including chromosome elimination (from 1 to 7 pairs per meiocyte), their increase to 34 pairs per meiocyte, polyvalents in combination with univalents whose frequencies were $11.5 \pm 1.9 \%$ and $15.0 \pm 2.5 \%$ in the crosses H. annuus ANN1064 $\times$ X1006-B and H. praecox $\times$ X908-B, respectively (Table 1).

The subsequent cytological analysis of meiosis in the interspecific hybrids showed that anomalies often occurred at the stage of metaphase I. Those were the univalents and the chromosomes not included into the metaphase plate (Table 2, Figure 1).

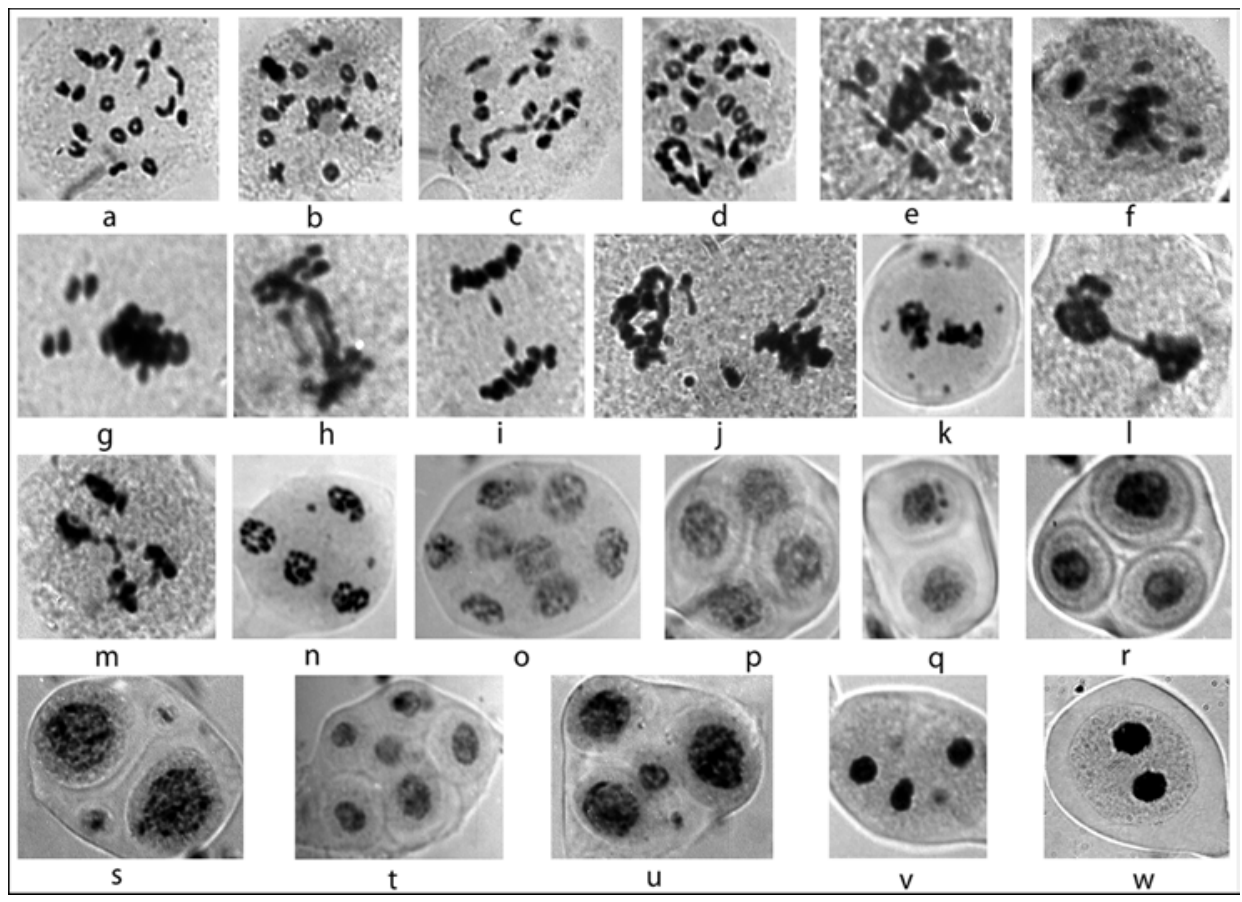

Figure 1: Photomicrographs of meiosis in the interspecific $F_{1}$ hybrids of sunflower: $a-17_{I I}$ in diakinesis, $b-18_{I I}$ in diakinesis, $c$ and $d$ - polyvalents in diakinesis, $e$ - lagging chromosomes in metaphase I, $f$ - chromosome asynapsis in metaphase I, $g$ chromosome desynapsis in metaphase I, $h$ - bridges in anaphase I, $i$ - lagging chromosomes in anaphase I, $j$ - lagging chromosomes in metaphase II, $k$ micronuclei in metaphase II, $l$ - bridge and lagging chromosomes in metaphase II, $m$ - lagging chromosomes in anaphase II, $n$ - micronuclei in telophase II, o - 8 nuclei in telophase II, $p$ - the normal tetrad, $q$ - the diad with 3 micronuclei, $r$ the triad, $s$ - tetrad with 2 reduced cells, $t$ - the hexad, $u$ - the tetrad with irregular nuclei, $v$ and $w$ - the picnotic nuclei. 


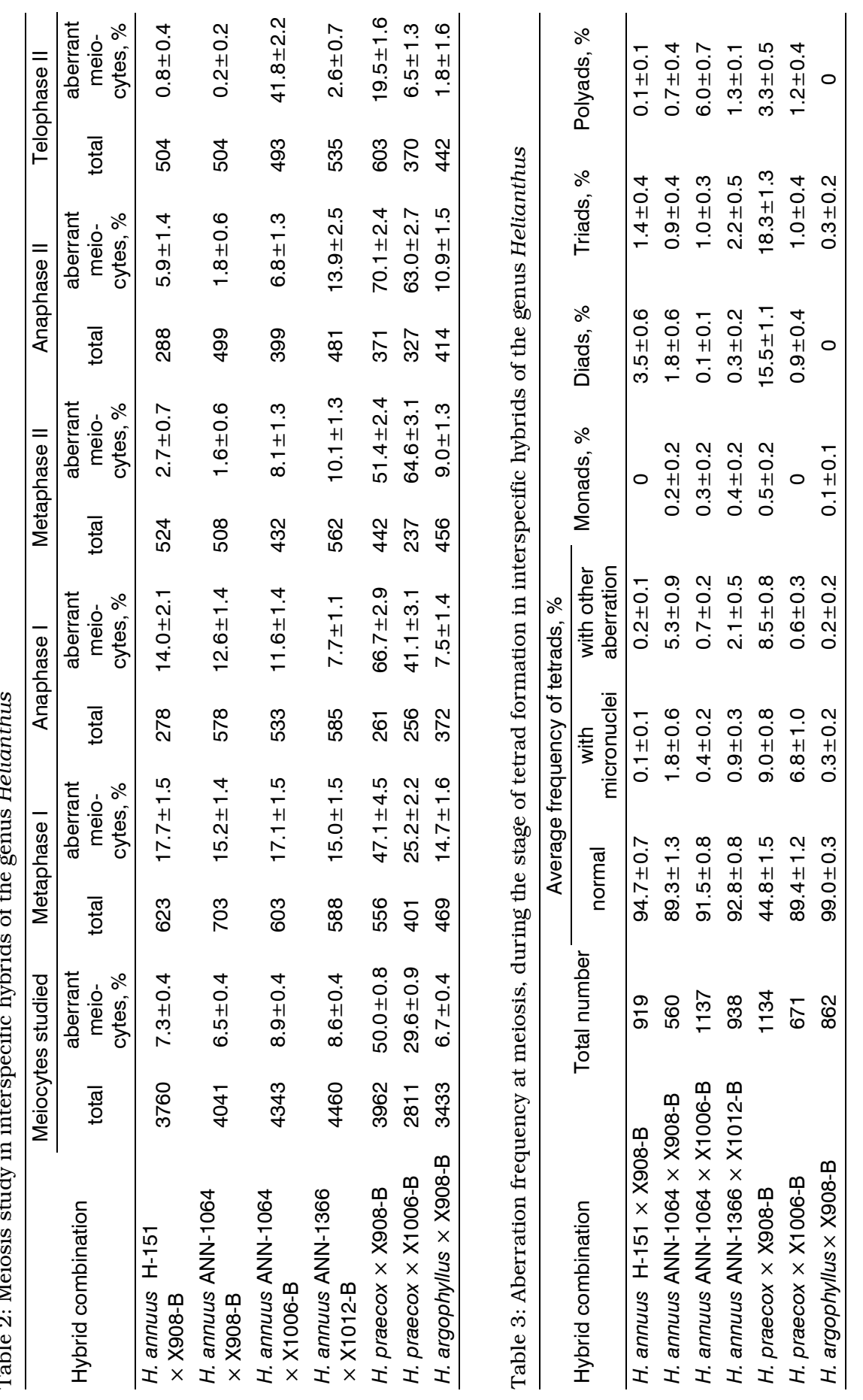


It was observed that the univalents in metaphase I occurred both as a result of absence of chromosome pairing (asynapsis), disorderly placement of chromosomes over the entire spindle and premature chromosome disjunction as a result of chiasmata absence (desynapsis) relatively to the basic groups of bivalents (Figure 1).

Bridges and chromosome disjunction were the basic aberrations observed at the stages of anaphase I and anaphase II. Lagging chromosomes and fragments of chromosomes as well as the bridges between metaphase plates which might have been preserved from the stage of anaphase I were found in metaphase II (Figure 1). There were lagging chromosomes, micronuclei, 2-3 and 5-8 poles of chromosome disjunction, irregularities of nuclei in the number of chromosomes, almost the bridges in telophase II.

Table 2 shows that the percentage of the aberrant meiocytes is more significant from metaphase I to telophase II in the interspecific hybrids derived from $H$. praecox as well as in diakinesis than these criteria in the other studied hybrids at all stages of meiosis ( $19.5-70.1 \%$ in $H$. praecox $\times$ X908-B and $6.5-64.6 \%$ in H. prae$\operatorname{cox} \times \mathrm{X} 1006-\mathrm{B})$. Minimal numbers of aberrant meiocytes $(0.2-15.2 \%)$ were also found in the interspesific hybrid $H$. annuus ANN1064 $\times$ X908-B in the mentioned period.

The second meotic division finishes simultaneously with tetrad formation and their location on sunflower microspores. The frequent formation of normal tetrads was reduced to $44.8 \%$ in $H$. praecox $\times \mathrm{X} 908-\mathrm{B}$, while this criterion was at the level of $89.3-99.0 \%$ in the other hybrids in this study (Table 3 ).

A wide range of aberrations such as tetrads with micronuclei resulting in chromosome elimination, tetrads with irregular number of chromosomes, pycnotical nuclei as well as monads, diads, triads and polyads was observed in the course of meiotic phases in the interspecific sunflower hybrids (Figure 1). Maximum numbers of these aberrations were found in the hybrid $H$. praecox $\times$ X908-B $19.0 \%$ tetrads with micronuclei, $15.5 \%$ diads, $18.3 \%$ triads, $3.3 \%$ poliads, $8.5 \%$ other aberrations).

The frequency of aberrations in telophase II was lower in the hybrid $H$. praecox $\times$ X1006-B than in $H$. praecox $\times$ X908-B. The decrease in the number of aberrant meiocytes observed in telophase II in these interspesific hybrids seems to be the result of restoration of some aberrations. The tetrads with micronuclei were predominant aberrations at the stage of the formation of tetrads in $H$. praecox $\times$ X1006-B $(6.8 \pm 1.0 \%)$.

The data obtained on meiotic progression in interspesific hybrids derived from wild species of $H$. annuus (Georgieva-Todorova, 1990; Georgieva-Todorova, 1993) and H. argophyllus (Manjula et al., 1999; Quillet, 1995) are similar to the results of other authors who also observed a normal meiosis with small aberrations. However, some authors noted a small number of aberrations during meiosis in hybrids of $H$. praecox (Georgieva-Todorova, 1993; Manjula et al., 1999; Quillet et al., 1995; Vassilevska et al., 1993). Chromosome associations $15_{\mathrm{II}}+1_{\mathrm{IV}}$ were observed in only 
8 out of 269 meiocytes (3\%) analyzed at diakinesis. It seems that such differences in results are associated with genotype peculiarities of parent forms (the structure and degree of affinity of the chromosomes involved in crosses of these genotypes). The high frequency of aberrations in $H$. praecox $\times H$. annuus, unlike in hybrids such as $H$. annuus (wild) $\times H$. annuus and $H$. argophyllus $\times H$. annuus, may explain phylogenetic relationships of these species. It was shown that $H$. annuus and $H$. argophyllus belong to the same cluster while $H$. praecox stays separately from them (Schilling et al., 1998; Schwarzbach et al., 2001). The noted meiotic peculiarities occurring in the hybrids between the wild species of $H$. annuus, $H$. argophyllus, $H$. praecox and the cultivated sunflower represent a different degree of homology of chromosomes belonging to $\mathrm{CH}$ genome $(C$ is a general ancestral genome for the whole genus Helianthus and $H$ is typical for the annual species only) (Sossey-Alaoi et al., 1996; Sossey-Alaoi et al., 1998). It is supposed that the frequency and patterns of aberrations in the interspecific sunflower hybrids result from amphyploidazation of the two genomes $(C$ and $H$ ) in the course of evolution of the genus Helianthus (Sossey-Alaoi et al., 1996). In order to evaluate and describe the exchange of genetic material between the crossed sunflower species, it is necessary to obtain data on chromosomes associated with specific marker genes, which allow to determine the genomic origin of the chromosomes, the availability of inversions in the karyotype and translocations between chromosomes. Such information are absent for the moment.

Thus, the study of meiosis in interspecific hybrids from the genus Helianthus has shown that the hybrids derived from the crossing with wild $H$. annuus and $H$. argophyllus are characterized by a small frequency of aberrations. It gives evidence of better balance of the chromosome complex of these hybrids than in the hybrids derived from $H$. praecox, particularly $H$. praecox $\times \mathrm{X} 908-\mathrm{B}$, in which the aberrations during meiosis reach $50 \%$. The number of normal tetrads was $89.4 \%$ in spite of a high frequency of aberrations occurring in the hybrid H. praecox $\times \mathrm{X} 1006-\mathrm{B}$ during meiosis.

\section{ACKNOWLEDGMENTS}

The authors express their graduate to Drs. R. A. Stebbins and L. F. Marek (North Central Regional Plant Introduction Station, Ames, Iowa, USA) for providing the seeds of wild sunflower species.

\section{REFERENCES}

Besard, G., Grivean, Y., Quillet, M.C., 1997. Specifying the introgressed regions from $H$. argophyllus in cultivated sunflower (Helianthus annuus L.) to mark Phomopsis resistance genes. Theor. Appl. Genet. 94: 131-138.

Cerboncini, C., Beine, G., Binsfeld, P.C., 2002. Source of resistance to Sclerotinia sclerotiorum (Lib.) de Bary in a natural Helianthus gene pool. Helia 25: 167-176. 
Gavrilova, V.A. \& Anisimova, I.N., 2003. Genetics of cultivated plants. Sunflower, pp. 16-36. St. Peterburg, VIR.

Georgieva-Todorova, J., 1990. Genetic and cytogenetic investigations of the genus Helianthus L., pp. 7-32. Publishing House of the Bulgarian Academy of Science, Sofia.

Georgieva-Todorova, J., 1993. Interspecific hybrydization and its application in sunflower breeding. Biotetechnology and Biotechnology Equipment 4: 153-157.

Jan, C.C., 2000. Cytoplasmic male sterility in two wild Helianthus annuus L. accessions and their fertility restoration. Crop Sci. 40: 1535-1538.

Lakin, G., 1980. Biometry, pp.102-134. Vishaya shkola, Moscow.

Manjula, T., Seetharam, A. \& Seenappa, K., 1999. Cytomorphological study in the interspecific hybrid Helianthus annuus L. $\times$ H. argophyllus T. \& G. Helia 22: 43-48.

Pausheva, Z., 1988. Plant Cytology Textbook, pp. 61-94. Moscow. Agropromizdat.

Popov, V.N., Yushkina, L.L., Sharypina, Ya.Yu. \& Kirichenko, V.V., 2005. Genotype peculiarities of crossability of cultivated sunflower with wide species and embryo culture use in interspecific hybridization. Tsitologia i Genetica 39: 3-8. (in Russian, with a summary in English).

Quillet, M.C., Madjidian, N., Griveau, Y., Serieys, H., 1995. Mapping genetic factors controlling pollen viability in an interspecific cross in Helianthus sect. Helianthus. Theor. Appl. Genet. 91: 1195-1202.

Schilling, E., Linder, R., Noyes, R. \& Rieseberg, L., 1998. Phylogenetic relationships in Helianthus (Asteraceae) based on nuclear ribosomal DNA internal transcribed spacer region sequence data. Systematic Botany 23: 177-187.

Schneiter, A. \& Miller, J., 1981. Description of sunflower growths stages. Crop Sci. 21: 901-903.

Schwarzbach, A., Donovan, L. \& Rieseberg, L., 2001. Transgressive character expression in a hybrid sunflower species. American Journal of Botany 88: 270-277.

Sossey-Alaoi, K., Serieys, H., Tersac, M., 1996. Phylogenetic relationships of Helianthus species based upon RAPD fragments: amphiploid origin of the genus. Compositae: Biology and Utilization (ed. Hind D.J.N.). Royal Botanic Gardens, Kew 2: 9-21.

Sossey-Alaoi, K., Serieys, H., Tersac, M., 1998. Evidence for several genomes in Helianthus. Theor. Appl. Genet. 97: 422-430.

Vassilevska, R. \& Telbizova, T., 1993. Hybridization of Helianthus praecox ssp. praecox Engl. \& Gray $(2 n=34)$ with cultivated sunflower Helianthus annuus L. $(2 n=34)$. III. Cytological studies on backcross and sib-pollinated generations. Biotechnology \& Biotechnology Equipment 4: 139-141.

\title{
INVESTIGACIONES CITOGENÉTICAS DE HÍBRIDOS INTERESPECIES F 1 DE LA SECCIÓN Helianthus
}

\author{
RESUMEN
}

Las propiedades citogenéticas durante la fase de meiosis, han sido estudiadas en las anteras de 7 interspecies del híbrido $\mathrm{F}_{1}$ obtenidos por el cruzamiento de las especies anuales silvestres (Helianthus annuus, H. praecox, $H$. argophyllus) con el girasol cultivado. Los híbridos derivados de las especies $H$. annuus y $H$. argophyllus se caracterizaban por baja frecuencia de aberaciones (6.5-8.6\%), lo que indica el equilibrio del complejo cromosomático de esos híbridos. Los híbridos derivados del cruzamiento entre $H$. praecox y el girasol cultivado, eran mucho menos estables y tenían alta frecuencia de aberación en la meiosis (29.6-50.0\%).

\section{ÉTUDE CYTOGÉNÉTIQUE DES HYBRIDES

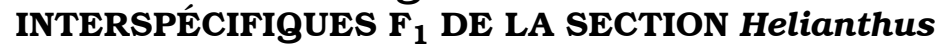

\author{
RÉSUMÉ
}

Les caractéristiques cytogénétiques ont été étudiées au cours de la phase méiotique dans les anthères de 7 hybrides interspécifiques $\mathrm{F}_{1}$ obtenus par le 
croisement des espèes sauvages annuelles (Helianthus annuus, H. praecox, $H$. argophyllus) avec le tournesol de culture. Les hybrides dérivés de $H$. annuus et $H$. argophyllus étaient caractérisés par une faible fréquence d'aberrations (6.5-8.6\%), ce qui démontre un bon équilibre du complexe chromosomique de ces hybrides. Les hybrides dérivés des croisements entre $H$. praecox et le tournesol de culture étaient beaucoup moins stables à cause de la haute fréquence d'aberrations dans la méiose (29.6-50.0\%). 
